\title{
ANALISIS PERBANDINGAN TERJEMAHAN UNGKAPAN YANG MENGANDUNG SIKAP SEKSIS ANTARA TOKOH LAKI-LAKI DAN PEREMPUAN DALAM NOVEL RONGGENG DUKUH PARUK
}

\author{
Maria Dita Manggarrani ${ }^{1}$ \\ M. R. Nababan ${ }^{2}$ \\ Universitas Sebelas Maret ${ }^{1,2,3}$ \\ dita.manggarrani@gmail.com ${ }^{l}$
}

\author{
Riyadi Santosa ${ }^{3}$
}

\begin{abstract}
Abstrak
Penelitian kualitatif deskriptif ini bertujuan untuk mengidentifikasi teknik penerjemahan yang digunakan penerjemah dalam mengalihbahasakan ungkapan yang mengandung sikap seksis, baik pada tokoh perempuan maupun tokoh laki-laki. Selain itu, penelitian ini juga bertujuan menemukan pergeseran terjemahan yang terjadi sebagai dampak dari penggunaan teknik penerjemahan. Data dalam penelitian ini berasal dari novel berbahasa sumber bahasa Indonesia yang berjudul 'Ronggeng Dukuh Paruk' dan terjemahannya yang berjudul 'The Dancer'. Peneliti menggunakan analisis taksonomi, komponensial dan tema budaya dalam menganalisis data. Hasil penelitian mengindikasikan bahwa terdapat 14 teknik penerjemahan yang digunakan pada tokoh perempuan. Di sisi lain, terdapat 12 teknik penerjemahan yang digunakan untuk mengalihbahasakan ungkapan yang mengandung sikap seksis pada tokoh laki-laki. Penerjemah cenderung menggunakan teknik kesepadanan lazim, baik pada tokoh perempuan maupun tokoh laki-laki. Teknik penerjemahan kreasi diskursif dan transposisi menyebabkan terjadinya pergeseran dalam bahasa sasaran.
\end{abstract}

Kata kunci: penerjemahan, teknik penerjemahan, pergeseran terjemahan, sikap seksis

\begin{abstract}
This qualitative descriptive research aims to identify the translation techniques used by the translator in translating expressions that contain sexist attitudes. It also aims to find the translation shift that occurred as a result of the translation techniques usage. The data were gained from an Indonesian novel entitled 'Ronggeng Dukuh Paruk' which is translated into the English novel entitled 'The Dancer'. The data were analyzed by taxonomy analysis, componential analysis, and cultural value analysis. The results of the study show that there are 14 translation techniques found on the women's character, while 12 techniques are used to translate sayings on men's characters. The translator tends to use established equivalence for both men's and women's characters. Discursive creation and transposition caused a translation shift.
\end{abstract}

Keywords: translation, translation techniques, translation shift, sexist attitude

\section{PENDAHULUAN}

Dalam karya sastra, isu tentang perempuan yang mendapat perlakuan seksis kerap dimunculkan. Seksisme yang tercipta seakan menjadi cerminan dari tradisi budaya yang wajar di masyarakat, bahwa sudah selayaknya wanita tunduk pada laki-laki. Novel-novel asli Indonesia yang 
mengusung isu tersebut, seperti Ronggeng Dukuh Paruk, bahkan diterjemahkan ke dalam beberapa bahasa asing, seperti Belanda, Jerman, Inggris dan Italia.

Mengalihbahasakan sebuah novel tentu bukanlah hal yang mudah, terutama bila terdapat perbedaan budaya pada bahasa sumber dan bahasa sasaran. Penerjemah tidak hanya wajib memiliki kompetensi bahasa yang baik, namun juga pengetahuan budaya agar hasil terjemahannya dapat berterima. Aspek penerjemah sebagai pengambil keputusan dalam penerjemahan menjadi sangat penting dan menjadi prioritas utama dalam sebuah penelitian (Nababan, 2007). Seorang penerjemah harus memiliki kompetensi kebahasaan, tekstual, kultural, bidang ilmu, strategik, dan transfer yang baik.

Sebagian besar pembaca tidak memiliki akses langsung ke bahasa sumber. Mereka sangat mengandalkan terjemahan yang dihasilkan oleh penerjemah. Maka, seorang penerjemah wajib bersikap tidak memihak terhadap salah satu lawan jenis. Pada teks ilmiah, penerjemah dituntut untuk memilih diksi yang tepat dan netral. Penerjemah bertugas menyampaikan makna dan pesan yang terdapat dalam bahasa sumber (Bsu) secara akurat. Berbeda halnya dengan penerjemah fiksi. Dalam menjaga keutuhan pesan dan gaya bahasa dari penulis, penerjemah tidak dapat semata-mata mengubah fungsi kategori kata menjadi tidak berbau seksis. Seorang penerjemah perlu menggunakan teknik penerjemahan yang tepat dalam mengalihbahasakan bahasa sumber ke bahasa sasaran.

Artikel ini merupakan pengembangan dari penelitian yang telah dilakukan sebelumnya. Pada penelitian yang telah dipresentasikan dalam 1st NASAL Conference Proceedings tersebut, peneliti (Manggarrani, Nababan, Santosa, 2019) menemukan seksisme dalam bahasa Indonesia yang pada hakekatnya merupakan bahasa netral. Seksisme yang terjadi bukan berupa bahasa, namun berupa sikap. Peneliti menemukan tiga jenis sikap seksis yang terjadi pada tokoh lakilaki dan perempuan dalam novel Ronggeng Dukuh Paruk, yaitu hostile sexism, benevolent sexism, dan modern sexism. Sikap tersebut disampaikan melalui ungkapan terhadap lawan jenis. Peneliti juga menyatakan bahwa penulis novel cenderung menggunakan sikap seksis negatif atau antipati. Hal ini dibuktikan dengan dominasi penggunaan sikap hostile sexism. Kecenderungan ini dipengaruhi oleh faktor eksternal penulis yang hidup dalam budaya patriarki.

Beberapa peneliti telah melakukan penelitian tentang seksisme dalam produk terjemahan. Pratiwi (2012), misalnya, melakukan penelitian tentang perbandingan bahasa seksis dalam novel Ressurection dan terjemahannya. Dalam penelitian tersebut, peneliti bertujuan untuk menemukan diksi yang mengandung seksisme, ciri bahasa seksis, dan jenis-jenis bahasa seksis. Sayangnya, peneliti tidak mengaitkannya dengan aspek penerjemahan, meskipun dalam judul tertulis perbandingan bahasa seksis dalam bahasa sumber dan bahasa sasaran. Rahmawati (2016) juga menemukan sifat-sifat seksis dan jenis-jenis bahasa seksis. Ia mengaitkan temuan tersebut dengan menganalisis teknik penerjemahan bahasa seksis dan juga dampak penggunaan teknik tersebut terhadap kualitas terjemahan dua novel, yaitu The Mistress's Revenge dan The 19th Wife. Namun, peneliti hanya memberi batasan analisis kualitas terjemahan pada aspek keakuratan dan keberterimaan saja. Dalam penelitian yang dilakukan oleh Nurochman (2017), ditemukan bahwa jenis-jenis bahasa seksis, teknik penerjemahan, dan kualitas penerjemahan pada dua penerjemah yang berbeda gender menunjukkan hasil yang berbeda. Peneliti juga menemukan bahwa penerjemah perempuan menghasilkan kualitas terjemahan yang lebih baik daripada penerjemah laki-laki. Peneliti tidak menganalisis aspek keterbacaan pada kualitas. Kemudian Nuraisiah (2018) menemukan adanya bahasa seksis dan sikap penulis serta penerjemah terhadap seksisme pada novel Gone Girl. Ia menggunakan teori apraisal dalam 
menganalisis sikap penulis dan penerjemah, lalu mengaitkannya dengan teknik penerjemahan dan kualitas penerjemahan.

Berdasarkan hasil penelitian tentang seksisme pada produk terjemahan yang telah dilakukan sebelumnya, peneliti menemukan beberapa rumpang penelitian. Pertama, kajian tentang seksisme cenderung dilakukan pada bahasa yang tidak netral atau seksis, seperti bahasa Inggris. Piercey (2000) menyebutkan bahwa bahasa Inggris adalah bahasa yang tidak netral. Hal ini dipengaruhi oleh budaya patriarki yang berkembang di negara tersebut. Penelitian tentang seksisme pada produk terjemahan yang menggunakan BSu netral seksis, khususnya bahasa Indonesia belum pernah dilakukan sebelumnya. Kedua, penelitian tentang seksisme dalam penerjemahan masih terbatas pada bahasa seksis dan sikap terhadap seksisme. Sikap seksis pada tokoh beda gender di dalam novel yang dikaitkan dengan penerjemahan, yaitu teknik penerjemahan dan pergeseran terjemahan belum pernah diteliti. Maka dalam penelitian ini, peneliti memilih novel yang menggunakan Bahasa Indonesia sebagai BSu. Novel tersebut telah diterjemahkan ke dalam Bahasa Inggris. Bahasa Indonesia dinilai sebagai bahasa yang netral terhadap seksisme, berbeda dengan Bahasa Inggris. Oleh karena itu, peneliti tertarik untuk mengkaji fenomena seksisme dalam novel berbahasa Indonesia tersebut. Penelitian ini dilakukan untuk mengetahui perbedaan teknik penerjemahan yang digunakan untuk mengalihbahasakan ungkapan yang mengandung sikap seksis pada tokoh laki-laki dan perempuan dalam novel Ronggeng Dukuh Paruk. Peneliti juga mengidentifikasi dampak penggunaan teknik penerjemahan pada pergeseran terjemahan dalam BSa (Bahasa Inggris).

\section{LANDASAN TEORI}

Peneliti menggunakan beberapa teori untuk menganalisis data dalam penelitian ini. Berikut adalah uraian teori yang digunakan peneliti.

\section{Pengertian Penerjemahan}

Penerjemahan merupakan sebuah kegiatan pengalihan pesan atau maksud penulis dari satu bahasa ke bahasa lain. Beberapa ahli mengemukakan teori tentang definisi penerjemahan. Catford (1965: 20) menyatakan "translation is the replacement of textual material in one language (SL) by equivalent textual material in another language”. Dengan kata lain, penerjemahan merupakan penggantian material teks bahasa sumber ke bahasa sasaran.

Kedua, diungkapkan oleh Newmark (1988: 5) "What is translation? Often, though not by any means always, it is rendering the meaning of a text into another language in the way that the author intended the text". Newmark berpendapat bahwa penerjemahan adalah proses penyampaian makna dari bahasa sumber ke bahasa sasaran, sesuai isi teks asli.

\section{Teknik Penerjemahan}

Molina \& Albir (2002: 509) mengungkapkan "translation techniques as procedures to analyse and classify how translation equivalence works". Dengan kata lain, teknik penerjemahan adalah alat yang digunakan untuk menganalisis dan mengklasifikasikan padanan kata Bsu dalam Bsa. Molina \& Albir (2002) mengklasifikasikan teknik penerjemahan ke dalam 18 jenis sebagai berikut: Adaptasi (Adaptation), Amplifikasi (Amplification), Peminjaman (Borrowing), Kalke (Calque), Kompensasi (Compensation), Deskripsi (Description), Kreasi Diskursif (Discursive Creation), Padanan Lazim (Established Equivalent), Generalisasi (Generalization), Amplifikasi 
Linguistik (Linguistic Amplification), Kompresi Linguistik (Linguistic Compression), Penerjemahan Harfiah (Literal Translation), Modulasi (Modulation), Partikularisasi (Particularization), Reduksi (Reduction), Subtitusi (Subtitution), Transposisi (Transposition), dan Variasi (Variation).

\section{Jenis-jenis Sikap Seksis}

Menurut Glick \& Fiske (1997), secara tradisional, seksisme dipandang sebagai sikap negatif terhadap wanita. Namun, seiring perkembangan zaman, ungkapan seksisme seakan menjadi netral meskipun hanya samar dan hanya diperhalus saja. Sarrasin (2011) mengelompokkan sikap seksis ke dalam tiga bentuk, yaitu (1) Modern sexism, yaitu cara pandang negatif yang diekspresikan secara lebih halus, (2) Hostile sexism, yaitu cara pandang negatif yang bertujuan untuk merendahkan salah satu gender, terutama wanita, dan (3) Benevolent sexism (paternalistik protektif, perbedaan gender komplementer, keintiman heteroseksual), yaitu prasangka terhadap perempuan dengan cara pandang yang positif. Dalam hal ini perempuan dianggap sebagai sosok yang harus dilindungi karena perempuan merupakan pelengkap pria, baik dalam hal seksualitas atau keseharian.

\section{METODE}

Penelitian kualitatif deskriptif ini bertujuan untuk memahami dan memaparkan fenomena budaya yang tersembunyi atau sedikit diketahui orang (Blaxter dkk., 2006; Moleong, 1989; Strauss \& Corbin, 2003 dalam Santosa, 2017: 31). Dalam penelitian ini, sumber data yang digunakan penulis adalah sebuah novel yang berjudul Ronggeng Dukuh Paruk yang diterjemahkan ke dalam bahasa Inggris dengan judul The Dancer. Lokasi penelitian dapat disebut juga sebagai batas yang digunakan untuk menentukan fokus penelitian atau focus determined boundary (Lyncoln \& Guba dalam Santosa, 2017: 123). Data dalam penelitian ini diperoleh dengan cara membandingkan novel terjemahan versi bahasa Inggris dengan versi aslinya, yaitu bahasa Indonesia. Data dalam penelitian ini terbagi menjadi dua, yakni (1) data primer, yang merupakan data penerjemahan (teknik penerjemahan dan pergeseran terjemahan) dan (2) data sekunder, yang merupakan penelitian-penelitian terkait yang telah dilakukan sebelumnya. Sumber data dalam penelitian ini diambil dari dua komponen yaitu: novel Ronggeng Dukuh Paruk dan hasil diskusi dengan informan dalam proses validasi data.

Novel Ronggeng Dukuh Paruk dipilih sebagai sumber data karena novel ini telah diterjemahkan ke banyak bahasa, salah satunya bahasa Inggris. Novel ini juga telah diadaptasi menjadi film sebanyak dua kali, pertama pada tahun 1983 dengan judul Darah dan Mahkota Ronggeng. Selanjutnya pada tahun 2011, novel ini kembali diangkat menjadi film berjudul Sang Penari. Film tersebut berhasil meraih sepuluh nominasi dalam Festival Film Indonesia dan memenangkan empat Piala Citra. Selain itu, setelah dilakukan observasi awal, terdapat banyak ungkapan yang mengandung sikap seksis dalam novel ini sehingga ketersedian data untuk penelitian dapat terpenuhi.

Teknik pengumpulan data yang digunakan adalah analisis dokumen. Dalam analisis dokumen, yang dilakukan oleh peneliti adalah membandingkan data dalam bahasa sumber dengan terjemahan versi bahasa Inggris, guna mengetahui teknik penerjemahan yang digunakan penerjemah. 
Untuk menjamin keabsahan data, peneliti menggunakan triangulasi sumber data dan triangulasi metode pemerolehan data. Salah satu teknik yang digunakan untuk mengembangkan keterpercayaan data adalah teknik triangulasi, yang terdiri dari triangulasi sumber data, metode pemerolehan data, peneliti, dan teori (Lyncoln \& Guba dalam Santosa, 2017: 131).

\section{TEMUAN DAN PEMBAHASAN}

Berikut adalah tabel tentang teknik penerjemahan yang digunakan oleh penerjemah untuk mengalihbahasakan ungkapan yang mengandung sikap seksis, baik pada tokoh perempuan maupun laki-laki.

Tabel 1. Data Teknik Penerjemahan Ungkapan yang Mengandung Sikap Seksis pada Laki-laki dan Perempuan

\begin{tabular}{|c|c|c|c|c|}
\hline No. & Gender & $\begin{array}{c}\text { Teknik } \\
\text { Penerjemahan }\end{array}$ & Jumlah & Persentase \\
\hline \multirow{14}{*}{1.} & \multirow{14}{*}{ Perempuan } & Padanan Lazim & 322 & $60,07 \%$ \\
\hline & & Eksplisitasi & 40 & $7,46 \%$ \\
\hline & & Modulasi & 37 & $6,90 \%$ \\
\hline & & Peminjaman Murni & 34 & $6,34 \%$ \\
\hline & & Implisitasi & 24 & $4,48 \%$ \\
\hline & & Parafrase & 20 & $3,73 \%$ \\
\hline & & Generalisasi & 15 & $2,80 \%$ \\
\hline & & Transposisi & 11 & $2,05 \%$ \\
\hline & & Adisi & 12 & $2,24 \%$ \\
\hline & & Reduksi & 8 & $1,49 \%$ \\
\hline & & Kreasi Diskursif & 7 & $1,36 \%$ \\
\hline & & Partikularisasi & 3 & $0,56 \%$ \\
\hline & & Kompensasi & 2 & $0,37 \%$ \\
\hline & & Delesi & 1 & $0,19 \%$ \\
\hline \multirow{12}{*}{2.} & \multirow{12}{*}{ Laki-Laki } & Padanan Lazim & 102 & $58,30 \%$ \\
\hline & & Modulasi & 16 & $9,14 \%$ \\
\hline & & Eksplisitasi & 13 & $7,43 \%$ \\
\hline & & Implisitasi & 13 & $7,43 \%$ \\
\hline & & Peminjaman Murni & 8 & $4,57 \%$ \\
\hline & & Parafrase & 7 & $4 \%$ \\
\hline & & Generalisasi & 6 & $3,43 \%$ \\
\hline & & Transposisi & 4 & $2,29 \%$ \\
\hline & & Adisi & 1 & $0,57 \%$ \\
\hline & & Reduksi & 2 & $1,14 \%$ \\
\hline & & Kreasi Diskursif & 2 & $1,14 \%$ \\
\hline & & Partikularisasi & 1 & $0,57 \%$ \\
\hline
\end{tabular}

Peneliti menemukan bahwa teknik penerjemahan yang digunakan untuk menerjemahkan ungkapan yang mengandung sikap seksis pada tokoh perempuan lebih banyak bila dibandingkan dengan tokoh laki-laki. Tokoh perempuan dalam novel Ronggeng Dukuh 
Paruk mendapatkan lebih banyak sikap seksis. Hal ini memengaruhi penggunaan teknik penerjemahan dalam mengalihbahasakan BSu ke BSa. Teknik penerjemahan yang digunakan untuk mengalihbahasakan ungkapan yang mengandung sikap seksis pada tokoh perempuan ada 14, yaitu padanan lazim, eksplisitasi, modulasi, peminjaman murni, implisitasi, parafrase, generalisasi, transposisi, adisi, reduksi, kreasi diskursif, partikularisasi, kompensasi, dan delesi. Di sisi lain, terdapat 12 teknik penerjemahan yang digunakan untuk mengalihbahasakan BSu ke BSa pada tokoh laki-laki, yaitu padanan lazim, modulasi, eksplisitasi, implisitasi, peminjaman murni, parafrase, generalisasi, transposisi, adisi, reduksi, kreasi diskursif, dan partikularisasi.

Teknik penerjemahan yang cenderung muncul adalah teknik kesepadanan lazim. Hal ini dibuktikan dengan 58,30\% frekuensi kemunculan teknik tersebut pada terjemahan ungkapan yang mengandung sikap seksis pada tokoh laki-laki dan $60,07 \%$ pada tokoh perempuan.

Contoh (1):

BSu: Lenggok lehernya, lirik matanya, bahkan cara Srintil menggoyangkan pundak akan memukau laki-laki dewasa mana pun yang melihatnya. (01.13.8.1)

BSa: The sweep of her neck, the glance of her eyes, even the way she swayed her shoukders would have mesmerized any adult male that saw her.

Penerjemah mengalihbahasakan frasa lenggok lehernya menjadi the sweep of her neck. Kata dalam frasa tersebut diterjemahkan dengan padanan kata yang lazim, dengan mempertimbangkan konteksnya.

Urutan ke dua, teknik penerjemahan yang banyak digunakan adalah eksplisitasi, yang digunakan sebanyak 40 kali pada tokoh perempuan dan 13 kali pada laki-laki. Teknik ini digunakan penerjemah dengan cara mengungkapkan istilah yang implisit pada bahasa sumber sehingga menjadi lebih mudah dipahami pada bahasa sasaran.

Contoh (2):

BSu: Makin mendekat ke pedukuhan itu makin terbayang olehnya akan sebuah tempat tidur berkelambu. Putih bersih dengan kasur dan bantal yang baru. Dan yang paling penting; seorang perawan kencur yang terbaring di dalamnya. (15.57.57)

BSa: The closer he got to the village, the more he fantasized about a mosquito-netted bed with a clean white mattress and pillow, and paramount in his mind a young girl in the bed.

Dalam menerjemahkan kata di dalamnya, penerjemah mengeksplisitkannya menjadi in the bed. Penerjemah langsung merujuk pada tempat yang dimaksud dengan kata di dalamnya tersebut, sehingga informasi yang tadinya tidak didapat secara gamblang, menjadi lebih jelas pada bahasa sasaran.

Teknik penerjemahan yang paling banyak digunakan selanjutnya adalah modulasi. Frekuensi penggunaan teknik tersebut sebanyak $6,90 \%$ pada tokoh perempuan dan $9,14 \%$ pada tokoh laki-laki. Penggunaan teknik ini dilakukan dengan cara mengubah sudut pandang pada bahasa sasaran.

Contoh (3):

BSu: Laki-laki yang dapat menyerahkan sejumlah uang yang ditentukan oleh dukun ronggeng, berhak menikmati virginitas itu. (11.51.51.2)

BSa: The man who can pay the amount of money determined by the dancer's trainer has the right to take his pleasure with this virgin. 
Penerjemah menerjemahkan yang dapat menyerahkan menjadi who can pay bukan who can give. Penerjemah mengubah kategori kognitif dalam kaitannya dengan teks dalam bahasa sumber.

Keempat, teknik penerjemahan peminjaman murni digunakan penerjemah untuk menerjemahkan pesan dalam bahasa sumber yang tidak dijumpai padanannya dalam bahasa sasaran. Frekuensi penggunaan teknik peminjaman murni sebanyak $6,34 \%$ pada tokoh perempuan dan $4,57 \%$ pada tokoh laki-laki. Dalam penelitian ini, teknik tersebut digunakan untuk menerjemahkan nama, baik nama orang maupun nama sebutan.

Contoh (4):

BSu: Yang baku, seorang laki-laki tergila-gila kepada ronggeng karena ronggeng memang dibuat untuk menarik hati laki-laki. Dia tidak boleh terikat kepada seorang pun. (41.115.121)

BSa: What's more typical is the man being crazy about the ronggeng. After all, she's made to attract men. She can't become attached to anyone.

Penerjemah menerjemahkan kata ronggeng tetap menjadi ronggeng. Penerjemah menggunakan teknik peminjaman murni. Dalam hal ini, kata ronggeng tidak memiliki padanan kata pada bahasa sasaran, maka kata tersebut tetap diterjemahkan dengan kata ronggeng.

Urutan ke lima, teknik penerjemahan yang digunakan adalah implisitasi. Teknik ini digunakan sebanyak 4,48\% untuk menerjemahkan ungkapan yang mengandung sikap seksis pada tokoh perempuan, 7,43\% pada tokoh laki-laki, dalam novel Ronggeng Dukuh Paruk. Penggunaan teknik ini bertujuan untuk mengimplisitkan informasi yang diberikan kepada pembaca dalam bahasa sasaran demi keefektifan hasil terjemahan.

Contoh (5):

BSu: Karena dalam kesadarannya sebagai ronggeng, Srintil merasa menjadi malam yang harus berpasangan dengan siang. Atau sejuk air yang harus menjadi penawar panasnya api.

BSa: As a ronggeng, Srintil believed that night is mated to day and cool air to hot fire. (80.223.244)

Pada contoh di atas, penerjemah mengalihbahasakan ungkapan yang mengandung sikap seksis dengan mengimplisitkan informasi. Maka, penerjemah menerjemahkan Karena dalam kesadarannya sebagai ronggeng menjadi as a ronggeng. Hal ini dilakukan penerjemah agar terjemahan yang dihasilkan menjadi lebih efektif.

Keenam, teknik penerjemahan parafrase digunakan penerjemah untuk menerjemahkan dengan cara memparafrase suatu informasi yang implisit dalam bahasa sumber. Dengan teknik ini, penerjemah berusaha menyampaikan ide dan pesan dalam bahasa sumber menjadi lebih umum dengan bahasa yang berbeda, yang sesuai dengan bahasa sasaran. Frekuensi penggunaan teknik parafrase sebanyak 3,73\% pada perempuan dan $4 \%$ pada tokoh laki-laki.

Contoh (6):

BSu: Mereka datang karena ingin membawa hati yang meriah. Yang masih anak-anak akan terpuaskan rasa ingin tahunya. Yang laki-laki dengan berahi atau nostalgia mereka. (65.212.232)

BSa: All visitors brought a sense of joy and excitement. The children would be satisfiedjust to watch. The men came either expecting to feel aroused with passion or with nostalgia for past passions. 
Penerjemah memparafrase kalimat Yang laki-laki dengan berahi atau nostalgia mereka menjadi The men came either expecting to feel aroused with passion or with nostalgia for past passions. Penerjemah menjaga pesan yang ditulis dalam bahasa sumber pada bahasa sasaran.

Ketujuh, teknik generalisasi digunakan oleh penerjemah untuk mengalihbahasakan informasi dalam bahasa sumber menjadi lebih umum sehingga mudah dipahami oleh pembaca. Hal ini dilakukan karena budaya pada bahasa sasaran tidak mengenal istilah yang spesifik pada bahasa sumber sehingga kata tersebut dicarikan padanan yang lebih umum. Penggunaan teknik generalisasi ini menolong pembaca memahami pesan yang disampaikan karena dapat berterima dalam konteks budaya pembaca bahasa sasaran. Frekuensi penggunaan teknik generalisasi sebanyak $2,80 \%$ untuk mengalihbahasakan ungkapan yang mengandung sikap seksis pada tokoh perempuan dan 3,43\% pada tokoh laki-laki.

Contoh (7):

BSu: Makin lama seorang suami bertayub dengan ronggeng, makin bangga pula istrinya. (06.39.)

BSa: The more a husband dances with a ronggeng dancer, the prouder his wife feels.

Penerjemah menggunakan teknik generalisasi untuk menerjemahkan kata bertayub menjadi dances dalam bahasa sasaran. Bertayub adalah spesialisasi dari menari, namun dalam bahasa sasaran, tidak terdapat padanan kata yang sesuai. Maka, kata bertayub diterjemahkan menjadi kata yang lebih umum, yaitu dances.

Kedelapan, teknik transposisi adalah teknik yang digunakan penerjemah dengan cara mengganti kategori grammatikal bahasa sumber dalam bahasa sasaran. Hal ini dilakukan karena adanya perbedaan tata bahasa antara bahasa sumber dan bahasa sasaran. Frekuensi penggunaan teknik transposisi sebanyak 2,05\% pada tokoh perempuan dan 2,29\% pada tokoh laki-laki.

Contoh (8):

BSu: Yang baku, seorang laki-laki tergila-gila kepada ronggeng karena ronggeng memang dibuat untuk menarik hati laki-laki. Dia tidak boleh terikat kepada seorang pun. (41.115.121)

BSa: What's more typical is the man being crazy about the ronggeng. After all, she's made to attract men. She can't become attached to anyone.

Pada contoh di atas, penerjemah menggunakan teknik transposisi untuk menerjemahkan karena ronggeng memang dibuat untuk menarik hati laki-laki menjadi After all, she's made to attract men. Penggunaan ini menyebabkan terjadinya unit shift dari klausa menjadi kalimat.

Kesembilan, teknik reduksi dilakukan dengan menghilangkan sebagian kata atau frasa. Penghilangan ini memungkinkan untuk dilakukan bila bagian yang dihilangkan tersebut tidak memengaruhi keutuhan pesan sebagaimana dalam ungkapan pada contoh di atas. Frekuensi penggunaan teknik reduksi sebanyak $1,49 \%$ untuk menerjemahkan ungkapan yang mengandung sikap seksis pada perempuan dan $1,14 \%$ pada laki-laki.

Contoh (9):

BSu: Seperti pernah dikatakannya kepadaku, Srintil lahir di Dukuh Paruk untuk menjadi ronggeng. Maka dengan rela hati dia akan menjalani malam buka-klambu, apa pula dengan kemungkinan baginya memiliki ringgit emas. (18.62.62.2)

BSa: As she had told me, she was born to become a ronggeng dancer and for that to happen she had to go through the bukak-klambu ritual. 
Konteks pada kalimat Maka dengan rela hati dia akan menjalani malam buka-klambu, apa pula dengan kemungkinan baginya memiliki ringgit emas. adalah proses atau tahapan-tahapan yang harus dilalui seorang perempuan, yang terpilih menjadi ronggeng. Penerjemah menghilangkan klausa apa pula dengan kemungkinan baginya memiliki ringgit emas. Teknik penerjemahan ini dilakukan untuk keefektifan hasil terjemahan dengan mereduksi beberapa kata, tanpa menghilangkan pokok informasi yang terkandung di dalamnya. Pesan yang terkandung dalam bahasa sumber tetap utuh tersampaikan dalam bahasa sasaran meskipun ada pengurangan kata.

Sepuluh, teknik adisi adalah teknik yang dilakukan dengan menambahkan kata dalam terjemahan. Penambahan ini disesuaikan dengan budaya pembaca dalam bahasa sasaran agar pembaca dalam bahasa sasaran mengerti tentang pesan apa yang terkandung. Namun, penambahan informasi yang berlebihan dapat mengubah makna dalam bahasa sumber. Frekuensi penggunaan teknik adisi sebanyak $2,24 \%$ pada tokoh perempuan dan $0,57 \%$ pada laki-laki.

Contoh (10):

BSu: Perawan kecil itu melayani bagaimana laiknya seorang ronggeng.

BSa: The little girl acoomodated them just as a ronggeng dancer might have done. (05.14)

Pada contoh di atas, penerjemah menggunakan teknik adisi untuk menambahkan informasi pelengkap dalam bsa. Hal ini dilakukan agar pembaca dalam bahasa sasaran lebih mengerti tentang istilah ronggeng dalam bahasa sumber. Penerjemah ingin menyampaikan bahwa ronggeng pada hakikatnya adalah seorang penari. Maka penerjemah menambahkan kata dancer sebagai informasi tambahan.

Sebelas, teknik kreasi diskursif digunakan oleh penerjemah dengan mencari padanan sementaranya, sehingga cenderung berbeda dengan makna aslinya. Padanan ini bertujuan untuk membuat terjemahan lebih berterima bagi pembaca, tetapi teknik ini cenderung menghasilkan terjemahan yang kurang akurat. Frekuensi penggunaan teknik kreasi diskursif dalam penelitian ini sebanyak $1,36 \%$ pada tokoh perempuan dan $1,14 \%$ pada tokoh laki-laki.

Contoh (11):

BSu: Srintil ingin memiliki hak memilih dan ikut menentukan dalam setiap urusan yang menyangkut dirinya. Memiliki dirinya bila hal itu menjadi kepentingannya, bukan kepentingan orang lain semata.

BSa: She was willing to give herself to a man, but only one she whom herself chose. (59.202.220.2)

Pada contoh di atas, penerjemah menggunakan teknik kreasi diskursif. Penerjemah menerjemahkan kalimat Srintil ingin memiliki hak memilih dan ikut menentukan dalam setiap urusan yang menyangkut dirinya menjadi She was willing to give herself to a man, but only one she whom herself chose. Teknik kreasi diskursif digunakan oleh penerjemah dengan mencari padanan sementaranya, sehingga hasil terjemahan cenderung keluar konteks dan berbeda dengan makna aslinya.

Dua belas, teknik partikularisasi merupakan kebalikan dari teknik generalisasi. Realisasi dari teknik ini adalah dengan menggunakan istilah yang lebih konkrit atau presisi (superordinatsubordinat). Dalam penelitian ini, frekuensi penggunaan teknik partikularisasi $0,56 \%$ pada perempuan dan $0,57 \%$ pada laki-laki. 
Contoh (12):

BSu: Atau lebih dari itu. Kesadarannya untuk mewakili dunia perempuan menumbuhkan rasa tanggung jawab ketika menghadapi seseorang yang mempunyai masalah kelelakian. Tanggung jawab itu secara naluri berlanjut menjadi kesadaran yang muncul dalam citra yang sempurna.

BSa: Yet there was more to it than that. Her desire to represent the world of women honed her sense of responsibility toward this boy who was unable to become a man. This sense of responsibility instinctively turned into a self-awareness out of which emerged a complete image of womanhood. (77.221.241.2)

Pada contoh di atas kata seseorang mengalami partikularisasi menjadi lebih spesifik, yaitu this boy. Teknik partikularisasi adalah kebalikan dari generalisasi. Pada kategori benevolent, teknik partikularisasi digunakan untuk menerjemahkan ungkapan yang mengandung sikap seksis pada perempuan saja. Teknik ini digunakan oleh penerjemah untuk menciptakan hasil terjemahan yang lebih konkrit (superordinat-subordinat).

Tiga belas, teknik kompensasi adalah teknik penerjemahan di mana penerjemah memperkenalkan unsur-unsur informasi atau pengaruh stilistik teks bahasa sumber di tempat lain dalam teks bahasa sasaran. Dalam penelitian ini, teknik kompensasi digunakan sebanyak $0,37 \%$ pada tokoh perempuan. Teknik ini tidak digunakan pada tokoh laki-laki.

Contoh (13):

BSu: Marsusi atau laki-laki mana saja tidak salah bila dia bermaksud mengawini ronggeng atau sekedar bersenang-senang.

BSa: Marsusi and other men may want to marry you or perharps just get together with you for a little diversion. They all know who you are, don't they? (95.288.323)

Pada contoh di atas, penerjemah menggunakan teknik kompensasi untuk mengalihbahasakan gaya bahasa penulis sekedar bersenang-senang ke dalam bahasa sasaran. Penerjemah mencoba memperkenalkan frasa tersebut kepada pembaca dengan menerjemahkannya menjadi just get together with you for a little diversion.

Teknik penerjemahan terakhir adalah teknik penerjemahan delesi yang digunakan sebanyak satu kali. Teknik ini hampir sama dengan reduksi, bedanya, dalam teknik ini terjadi penghilangan secara total. Penerjemah menggunakan teknik delesi untuk mengalihbahasakan ungkapan yang mengandung sikap seksis pada tokoh perempuan saja.

Contoh (14):

BSu: Yang kuserahi keris itu adalah perempuan sejati, perempuan yang hanya ada dalam angan-angan, yang terwujud dalam diri Srintil yang sedang tidur. Tentu saja perempuan yang kumaksud adalah lembaga yang juga mewakili Emak, walau aku tidak pernah tahu di mana dia berada.

BSa: I was surrendering the keris to a true woman, one who lived only in the realm of my fantasy, but was embodied in the sleeping Srintil. (09.41.38)

Pada contoh di atas, penerjemah mengalihbahasakan BSu ke BSa dengan melakukan delesi. Sayangnya, penghilangan yang dilakukan bersifat total. Dengan kata lain, ungkapan yang mengandung sikap seksis di atas tidak terjemahkan ke dalam bahasa sasaran atau dihapus.

Teknik penerjemahan yang mendominasi pada tokoh perempuan adalah kesepadanan lazim, eksplisitasi, dan modulasi. Hal ini berbeda dengan ungkapan yang mengandung sikap 
seksis pada laki-laki. Peneliti menemukan bahwa penerjemah juga menggunakan ketiga teknik serupa, namun dengan urutan yang berbeda. Teknik kesepadanan lazim tetap menjadi teknik yang paling mendominasi, lalu diikuti dengan teknik modulasi, dan eksplisitasi. Peneliti juga menemukan beberapa pola penerjemahan. Pada tokoh perempuan di dalam novel, penerjemah cenderung mencari padanan kata yang sesuai pada bahasa sasaran. Kedua, penerjemah melakukan eksplisitasi dari informasi-informasi yang sebelumnya hanya disampaikan secara implisit oleh penulis. Terakhir, penerjemah melakukan perubahan sudut pandang dalam menghasilkan terjemahan yang berterima dalam bahasa sasaran. Pada tokoh laki-laki, penerjemah lebih mencari padanan kata yang lazim digunakan oleh pembaca dalam bahasa sasaran, lalu melakukan perubahan sudut pandang dalam terjemahan. Perubahan sudut pandang dapat dilakukan penerjemah untuk menyesuaikan struktur kebahasaan pada bahasa sasaran. Terakhir, penerjemah melakukan eksplisitasi istilah atau informasi yang implisit. Teknik penerjemahan yang paling jarang digunakan pada tokoh perempuan adalah delesi, sedangkan pada tokoh laki-laki adalah partikularisasi dan adisi. Masing-masing teknik tersebut hanya digunakan satu kali oleh penerjemah. Dampak penggunaan teknik penerjemahan terhadap pergeseran terjemahan dijelaskan di bawah ini.

Tabel 2. Pergeseran Terjemahan Ungkapan yang Mengandung Sikap Seksis pada Laki-Laki dan Perempuan

\begin{tabular}{|c|c|c|c|}
\hline No. & Gender & $\begin{array}{c}\text { Teknik } \\
\text { Penerjemahan } \\
\end{array}$ & Pergeseran \\
\hline \multirow{14}{*}{1.} & \multirow{14}{*}{ Perempuan } & Kesepadanan lazim & \multirow{7}{*}{ Tidak Bergeser } \\
\hline & & Modulasi & \\
\hline & & Eksplisitasi & \\
\hline & & Peminjaman Murni & \\
\hline & & Implisitasi & \\
\hline & & Parafrase & \\
\hline & & Generalisasi & \\
\hline & & Transposisi & Bergeser \\
\hline & & Reduksi & \multirow{2}{*}{ Tidak Bergeser } \\
\hline & & Adisi & \\
\hline & & Kreasi Diskursif & Bergeser \\
\hline & & Partikularisasi & \multirow{3}{*}{ Tidak Bergeser } \\
\hline & & Kompensasi & \\
\hline & & Delesi & \\
\hline \multirow{10}{*}{2.} & \multirow{10}{*}{ Laki-laki } & Kesepadanan lazim & \multirow{8}{*}{ Tidak Bergeser } \\
\hline & & Modulasi & \\
\hline & & Eksplisitasi & \\
\hline & & Peminjaman Murni & \\
\hline & & Implisitasi & \\
\hline & & Parafrase & \\
\hline & & Generalisasi & \\
\hline & & Transposisi & \\
\hline & & Kreasi Diskursif & Bergeser \\
\hline & & Partikularisasi & Tidak Bergeser \\
\hline
\end{tabular}


Berdasarkan analisis yang telah dilakukan, pergeseran terjemahan disebabkan oleh pengaplikasian teknik penerjemahan dalam mengalihbahasakan bahasa sumber ke bahasa sasaran. Peneliti menemukan bahwa pergeseran terjemahan terjadi satu kali pada tokoh perempuan dan satu kali pada tokoh laki-laki. Teknik yang memengaruhi terjadinya pergeseran adalah teknik kreasi diskursif dan transposisi. Teknik kreasi diskursif menyebabkan hasil terjemahan menjadi tidak akurat, makna serta ide penulis dalam BSu tidak dapat tersampaikan dengan baik pada BSa. Sedangkan teknik transposisi menyebabkan terjadinya unit shift pada terjemahan.

\section{Contoh (15):}

BSu: Laki-laki memang kurang ajar.

BSa: Those young men are so rude. (24.83.85.1)

Ungkapan di atas merupakan stereotip negatif yang bertujuan merendahkan salah satu gender, yaitu laki-laki. Stereotip negatif yang awalnya hanya untuk seorang laki-laki berubah dan menjadi berlaku secara konvensional, yaitu bagi setiap laki-laki. Sikap seksis yang terdapat dalam ungkapan tersebut berubah fungsi menjadi tidak seksis pada BSa. Penerjemah menggunakan dua teknik, yaitu kesepadanan lazim dan kreasi diskursif. Dalam hal ini, teknik kesepadanan lazim tidak menimbulkan pergeseran dalam bentuk apapun. Pergeseran fungsi kategori seksis ini dipengaruhi oleh pengaplikasian teknik kreasi diskursif. Teknik kreasi diskursif yang digunakan oleh penerjemah menyebabkan terjadinya pergeseran fungsi dari seksis menjadi tidak seksis. Laki-laki memang kurang ajar merupakan ungkapan yang mengandung sikap seksis karena pandangan negatif ini berlaku untuk semua laki-laki. Penerjemah menerjemahkannya menjadi Those young men are so rude. Kalimat ini menjadi tidak seksis karena pandangan negatif ini merujuk pada sekelompok laki-laki, bukan semua laki-laki. Penggunaan teknik kesepadanan lazim pada ungkapan di atas tidak menyebakan terjadinya pergeseran fungsi. Penerjemah menggunakan teknik tersebut untuk mencari padanan kata yang sesuai pada BSa, tanpa mengubah struktur gramatikal dan makna yang terkandung.

Contoh 16:

BSu: Laki-laki membenci apa-apa yang kendur!

BSa: ... and they hate flabbiness! (25.83.85.2)

Pada contoh di atas, penerjemah menggunakan teknik kreasi diskursif, kesepadanan lazim, dan transposisi. Dalam hal ini, pergeseran yang terjadi disebabkan oleh penggunaan teknik kreasi diskursif dan transposisi. Teknik kreasi diskursif menyebabkan hasil terjemahan menjadi tidak akurat karena makna yang dihasilkan dalam BSa cenderung berbeda dengan BSu. Begitu juga dengan transposisi, teknik ini menyebabkan terjadinya pergeseran unit. Transposisi adalah teknik yang digunakan penerjemah dengan cara mengganti kategori grammatikal bahasa sumber ke dalam bahasa sasaran. Penggunaan teknik kesepadanan lazim tidak memengaruhi pergeseran fungsi pada ungkapan sikap seksis. Penerjemah menggunakan teknik ini untuk mencari padanan kata yang sesuai dalam BSa, tanpa merubah struktur gramatikal, sudut pandang, dan makna yang terkandung. 


\section{KESIMPULAN}

Penerjemah cenderung menggunakan teknik kesepadanan lazim dalam mengalihbahasakan bahasa sumber ke bahasa sasaran. Hal ini dibuktikan dengan adanya dominasi penggunaan teknik kesepadanan lazim, baik pada tokoh perempuan maupun laki-laki. Kesamaan yang masih berkembang di negara-negara dengan budaya patriarki tidak menyebabkan penerjemah kesulitan menemukan padanan kata yang sesuai. Di balik kenetralannya, bahasa Indonesia memiliki latar belakang sikap seksis dalam masyarakat sosial, begitu juga dengan bahasa Inggris. Hal inilah yang diasumsikan menjadi pertimbangan penerjemah dalam mengalihbahasakan ungkapan yang mengandung sikap seksis dengan teknik kesepadanan lazim, baik pada tokoh perempuan maupun laki-laki. Perempuan mendapatkan lebih banyak sikap seksis daripada laki-laki, maka teknik penerjemahan yang digunakan oleh penerjemah juga lebih bervariasi pada tokoh perempuan. Produk terjemahan yang dihasilkan oleh penerjemah tidak banyak mengalami pergeseran menjadi tidak seksis atau netral. Meskipun begitu, peneliti menemukan dua pergeseran fungsi kategori dalam penelitian ini. Kedua pergeseran ini terjadi satu kali pada tokoh laki-laki dan satu kali pada perempuan. Dengan kata lain, kecenderungan teknik penerjemahan yang digunakan oleh penerjemah tidak menyebabkan terjadinya pergeseran yang signifikan. Teknik yang menyebabkan terjadinya pergeseran adalah kreasi diskursif dan transposisi.

Penelitian ini dapat memberikan gambaran tentang pemilihan teknik penerjemahan yang dilakukan oleh penerjemah dalam mengalihbahasakan ungkapan yang mengandung sikap seksis pada laki-laki dan perempuan. Pembaca juga dapat melihat bagaimana dampak penggunaan teknik penerjemahan terhadap pergeseran terjemahan. Bagi peneliti lain, penelitian ini dapat menjadi acuan untuk melakukan penelitian lanjutan, misalnya dengan membandingkan teknik penerjemahan dari dua penerjemah, atau dua sumber data yang berbeda namun satu penerjemah. Dari situ akan lebih terlihat perbedaan pemilihan teknik dan kekonsistenan penerjemah.

\section{CATATAN}

Penulis berterima kasih kepada mitra bebestari yang telah memberikan masukan yang berharga untuk meningkatkan kualitas makalah ini.

\section{DAFTAR PUSTAKA}

Badan Pengembangan dan Pembinaan Bahasa, Kementerian Pendidikan dan Kebudayaan Republik Indonesia. (2017). Kamus Besar Bahasa Indonesia. Edisi ke-4.

Bell, R.T. (1991). Translation and translating: Theory and Practice. New York: Longman.

Catford, J.C. (1965). A linguistic theory of translation. Oxford: Oxford University Press

Glick, P., \& Fiske, S. T. (2001). Ambivalent stereotypes as legitimizing ideologies: Differentiating paternalistic and envious prejudice. In J.T. Jost \& B. Mayor (Eds.), The psychology of legitimacy. Emerging perspectives on ideology, justice, and intergroup relations (hlm. 278-306). Cambridge, UK: Cambridge University Press.

Manggarrani, M. D, Nababan, M., Santosa, R. (2019). Sikap seksis dalam novel Ronggeng Dukuh Paruk. 1st NASAL Conference Proceedings.Yogyakarta: Universitas Negeri Yogyakarta. 
Nababan, M. R. (2007). Aspek genetik, objektif, dan afektif dalam penelitian penerjemahan. Linguistika. Volume 14(26).

Nababan, Mangatur. dkk. (2012). Pengembangan model penilaian kualitas terjemahan. Kajian Linguistik dan Sastra. Volume 24(1).

Newmark, Peter. 1988. A Textbook of translation. London: Prentice Hall International.

Nuraisiah, S, Nababan, M., Santosa, R. (2018). Translating attitudes toward sexism in Gone Girl novel: An appraisal theory approach. Jurnal Lingua Cultura, Vol.12(3).

Nurochman, Nababan, M., Santosa, R., Kristina, D. (2017). Translation quality of sexist language in the novel Little Women by Loisa May Alcott. 6th ELTL Conference Proceedings. Semarang: Universitas Negeri Semarang.

Piercey, M. (2000). Sexism in the English language. TESL Canada Journal. Vol. 17(2).

Santosa, R. (2017). Metode penelitian kualitatif. Surakarta: UNS Press.

Venuti, L. (1995). The translator's invisibility: A history of translation. London \& New York: Routledge.

Wardhaugh, R. (2006). An introduction to Sociolinguistics, Fifth Edition. Victoria: Blackwell Publishing. 